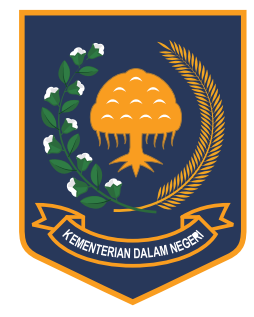

Jurnal Bina Praja 9 (2) (2017): 243 - 253

Jurnal Bina Praja

e-ISSN: 2503-3360 | p-ISSN: 2085-4323

Accreditation Number

735/AU2/P2MI-LIPI/04/2016

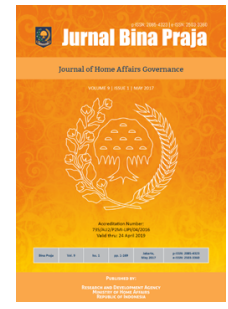

http://jurnal.kemendagri.go.id/index.php/jbp/index

\title{
GOVERNMENT STRATEGY \\ IN THE ERADICATION OF DENGUE HEMORRHAGIC FEVER (DHF) IN JAMBI CiTY
}

\author{
Novia Susianti * \\ Regional Research and Development Agency (Balitbangda) of Jambi Province \\ Jl. R.M. Noor Atmadibrata No. 1A
}

Received: 3 July 2017; Accepted: 13 October 2017; Published online: 28 November 2017

DOI: $10.21787 /$ jbp. 09.2017.243-253

\begin{abstract}
The mortality rate and the distribution of dengue fever case in Indonesia tend to increase. Jambi Province is the province with the highest mortality rate in Indonesia in 2013, and Jambi City is the highest contributor for the last 3 years. Eradication efforts have been made, but they have not been able to break the chain of transmission. This research uses descriptive design with a qualitative approach to identify the causes of inaccuracy of eradication efforts and to determine the strategy of eradicating dengue fever in Jambi City. Site selection was done by purposive sampling, with the highest incidence rate criterion in 2015. The informants were chosen based on the criteria of conformity and adequacy, covering the Health Department, the Puskesmas, the sub-district and the community i.e. the larva monitoring cadre (jumantik). The assessment scheme is based on government policy implementation scheme in eradicating DHF by the identification of factors based on ultrasound analysis (Urgency, Serious, Growth). The strategy of eradication efforts is based on SWOT analysis (Strenght, Weaknesses, Opportunities, Threats). The determination of alternative strategies was chosen based on Mc. Namara's screening theory, with 5 criteria of effectiveness, ease, benefits, time, and cost. The result of the research shows that the inaccuracy of dengue eradication efforts in Jambi City lies in the ineffectiveness of the implementation of the Mosquito Nest Eradication (PSN) movement through cross-sector integration in community empowerment routinely and independently. The main strategy that can be done by the government is to increase the role of larva monitoring cadres and larva monitoring students (sismantik) through budget support from across sectors in campaigning PSN movement regularly, either at house or institution environment.
\end{abstract}

Keywords: Filtering Analysis, Dengue, Jumantik Cadre

\section{INTRODUCTION}

Dengue Haemorrhagic Fever (DHF) continues to fluctuate annually and the number of morbidity and the distribution of affected areas are increasing (Achmadi, 2010; Ministry of Health of the Republic of Indonesia, 2015; Sukowati, 2010). The disease transmitted through the bite of Aedes aegypti mosquitos can only be controlled through vector control by breaking the transmission chain through Mosquito Nest Eradication (PSN), especially since the vaccine for prevention of viral infection and Dengue medicines are yet to be found. However, the vector control in almost all countries and endemic countries is not well targeted, unsustainable, and has not broken the transmission chain yet (Achmadi,
2010; Sukowati, 2010).

Sukowati stated the cause lies in the applied method that has not been able to refer to the data/ information about the vector. In addition, it still relies on the use of insecticide by spraying and larviciding (Sukowati, 2010). The statement was proven through several research results which concluded that the use of insecticides actually raises new problems of the emergence of vector resistance. Sayono, Syafruddin, \& Sumanto (2012) who conducted a study on the distribution of Aedes aegypti mosquito resistance against the Sipermetrin insecticide that has been used in Indonesia for 10 years, found that the density of Aedes aegypti population in Semarang has exceeded the safe limits

\footnotetext{
* Corresponding Author

Phone : +6281274511108

Email : susiantinovia@gmail.com
} 
of DHF transmission established by WHO (5\%) with mosquito deaths ranging from 0.8 to $13.5 \%$, averaging to $5.88 \%$ with resistance status. Sunaryo, Ikawati, Rahmawati, \& Widiastuti (2014) found that Aedes aegypti mosquito resistance against $0.8 \%$ Malathion insecticide and $0.25 \%$ permethrin in Semarang City, Kendal District, and Purbalingga District that reached $100 \%$ high resistance to organophosphate group.

Indeed, the eradication of dengue disease has been regulated through the Decree of the Minister of Health of the Republic of Indonesia Number 581/Menkes/SK/VII/1992, but it turns out that Indonesia, in the map of outbreaks of DHF, is in a position of concern both before and after the issuance of the decision. Outbreaks of DHF occurred several times in 1973, 1977, 1978, 1983, 1988, 1996, 1998, 2007, and 2009. The highest cases of DHF outbreaks over the last ten years were in 2009 with 154,855 cases and the number of people who died as many as 1,384 people. The increase in the number of cases is more than twice compared to the outbreak of DHF in 1998, which was as many as 72,133 with the death of 1,414 people (Ministry of Health of the Republic of Indonesia, 2011). By 2014, the dengue fever in 433 districts/municipalities is with the morbidity rate of 39.83 per 100,000 population, with mortality rates under $1 \%$, but is expected to increase and expand in distribution (Ministry of Health of the Republic of Indonesia, 2015).

Taking into account the conditions of concern, the eradication efforts that have been set in the Decree of the Minister of Health of the Republic of Indonesia Number 581/Menkes/SK/VII/1992 should be put forward this time. This study supports the eradication program as listed in the decree with the consideration of many found dengue vector resistance due to the use of insecticides. In addition, the emphasis of eradication efforts contained in the decree lies in cross-sectoral cooperation and community participation on a continuous basis in breaking the transmission chain through the Eradication of Mosquito Nest (PSN).

The Minister of Home Affairs endorsed the decision by issuing an order to the Governor and Regent/Mayor to follow up in the form of a Decree of the Regional Head to coordinate the relevantagencies in the eradication of Dengue Fever, formulate implementation, conduct community participation, immediately establish Operational Working Group for the Eradication of Dengue Hemorrhagic Fever (Pokjanal DHF), and preparing operational funds that are incorporated into the APBD. It can be seen from the decree that the eradication efforts prioritize the cooperation of all parties in vector control in the form of mobilization of the community to do PSN. Due to the environmentally-based DHF vector, the mobilization of the community is unlikely to succeed well without the role of Local Government and inter-related sectors such as education, religion, NGOs and so on (Sukowati, 2010).

The importance of community participation in the control of DHF vector in the form of PSN movement has proven to have raised entomological indicator of larvae free rate (ABJ) and the decreasing number of DHF patients. This has been proven with several studies by Trapsilowati, Mardihusodo, Prabandari, \& Mardikanto (2015), Sungkar (2007), Trapsilowati \& Widiarti (2013), which concluded that entomologic indicators of $\mathrm{ABJ}$ tend to increase in areas with community empowerment in controlling the DHF vectors. However, community empowerment lies not only in the policy that has been issued since a policy will not produce anything if it is not followed by supporting activities related to the program.

Similarly, in Jambi City, as the city with the highest number of dengue fever in Jambi Province, the Mayor of Jambi has issued Instruction of the Mayor of Jambi Number 196 of 2015 on Control and Eradication of Dengue Fever in Jambi City with the implementation of a PSN movement called One Hour One Week, simultaneously done on Friday in all Government Agencies, Private, Shops, Schools, Means of Worship and Public Places, and on Sunday in their houses by inviting all members of the community. The instruction continued with the second Instruction of the Mayor of Jambi Number 1 of 2016 on the Management of Dengue Disease through Attempts to Eradicate Mosquito Nest, Abatisation and Implementation of Fogging in Jambi City. In addition to issuing the policy, the Mayor of Jambi has also provided assistance to the community through the sub-districts in the form of a fogging machine where the implementation is by coordinating with the Puskesmas.

However, Jambi City is still the second-tier region in Jambi province with the highest incidence rate (IR) in Jambi Province in the last 3 years. In 2014 , there were 661 people (IR 112.62) with an 11-person fatality rate (CFR 1.82), decreased to 575 patients (IR 99.81) with a mortality rate of 8 people (CFR 1.39) in 2015, and increased again to 631 patients (IR 107.51) with the number of deaths per April 2016 with 7 people (CFR 1.11) (Jambi Provincial Health Office, 2016). Another condition found is that the PSN activities are rarely implemented, as well as cross-sectoral activities in the prevention of dengue fever in Jambi City, the number of dengue fever from year to year is increasing, and the larvae free rate $(\mathrm{ABJ})$ has not fulfilled the national target of $\geq 95 \%$, which is $89.97 \%$ in $2013,91.11 \%$ in 2014 , and declining to $89.08 \%$ in 2015.

The policies that have been issued need to be 
supported by activities, including policies related to DHF control. The importance of supporting activities in the DHF prevention program has been proven by several studies. Trapsilowati \& Widiarti (2013) found that the implementation of policies related to the prevention of DHF in Pati Regency has not been followed by supporting activities, both at the level of the program or at the level of the community with $\mathrm{ABJ}$ that is still far below target. Massi (2016) who conducted research on the implementation of DHF control policy at Talise Health Center in Palu found that the implementation of DHF control policy in Talise Puskesmas of Palu City has not been effective in reducing the number of dengue fever patients due to communication factors, resources, and bureaucratic structure.

Given that the Mayor of Jambi has issued a policy related to the eradication of DHF but the fact that the high Incidence Rate (IR) of DHF and Mud Free Number $(A B J)$ is still far from the national target, this research is different from the previous research. This research explored the factors causing the inaccuracy of eradication efforts that have been done, based on Decree of the Minister of Health of the Republic of Indonesia Number 581/Menkes/ SK/VII/1992, as well as determined the eradication strategy based on the analysis of existing conditions in Jambi City.

\section{METHOD}

This research uses descriptive design with the qualitative approach to identify the causes of inaccuracy of eradication efforts and to determine the strategy of eradicating dengue fever in Jambi City. The research was conducted in June to October 2016 in Jambi City, where the selection of subdistrict and Urban Village location was done by purposive sampling, with the highest incidence rate criterion in 2015, namely Kota Baru Subdistrict and Kenali Asam Atas Urban Village.

The informants were chosen based on the criteria of suitability and adequacy, consisting of DHF program holders in Jambi District Health Office, Head of Pall X Public Health Center, Holder of Puskesmas Pall X DHF Program, Kenali Asam Atas Urban Village Office, Neighborhood head, and larva monitoring cadres (Jumantik) in Urban Village. The primary data were obtained from observation, indepth interview, and Focus Discussion Group (FGD), while the secondary data were obtained from document studies related to DHF program.

The scheme of assessment is based on government policy implementation scheme in eradicating DHF through several aspects, namely organizing aspect, coaching aspect, financing aspect, and implementation aspect. The identification of factors based on ultrasound analysis (Urgency, Serious, Growth). The strategy of countermeasures is based on SWOT analysis (Strength, Weaknesses, Opportunities, Threats). The determination of alternative strategies was chosen based on Mc. Namara's screening theory with 5 criteria of effectiveness, ease, benefits, time and cost. Each criterion is given a score of values between 1 and 5 . The highest total score is the solution of the problem (Sianipar \& Entang, 2001).

\section{RESULTS AND DISCUSSION}

Based on the objectives that have been determined, the results of this study are discussed through the identification of factors causing the inaccuracy of efforts to eradicate and the determination of strategies to eradicate dengue in Jambi City.

\section{A. The Identification of Causes of Inaccurate Efforts in Eradicating DHF in Jambi City}

The identification of the causes of DHF Eradication inaccuracy in Jambi City refers to the Decree of the Minister of Health Number $581 / 1992$ on guidance on the implementation of the eradication of DHF (Decree of the Minister of Health of the Republic of Indonesia Number 581/ Menkes/SK/VII/1992 on Eradication of Dengue Hemorrhagic Fever, 1992), covering the aspects of organizing, coaching, financing, and implementation consisting of prevention, discovery, prevention, as well as extension to the community.

In the organizing aspect, DHF Working Group (Pokja) has been established at the village/urban village level. This is evident with the presence of Jumantik cadres in each urban village, based on the Decree (SK) from the PKK District Activity Team Head. In the implementation aspect, the function of DHF Pokja has not run maximally; it is because the budget at the urban village or sub-district level has not been pro-active in the empowerment of Pokja. Although some sub-districts in Jambi City have budgeted for DHF control, the budget is limited to fogging. On the other hand, the implementation of fogging has not been effective yet, because the executive officers are still from Puskesmas/Health Office in Jambi City.

In the aspect of coaching, has been formed an Operational Working Group (Pokjanal) for the Eradication of DHF in Jambi City through Mayor of Jambi Decree. Pokjanal Secretariat is located in the Kesra Section of Jambi City with members consisting of related institutions, sub-district, and PKK. However, the team is not formed in each subdistrict and at the stage of implementation has not run maximally, as seen from the absence of meetings of the Pokjanal team in Jambi City in 2016. The meeting was only held by the sub-district with high 
incidence and the DHF as initiated by Puskesmas and is limited to districts with a high incidence of DHF.

In the financing aspect, there is no integrated financing program among agencies involved in the DHF eradication program. Dengue fever program planning process is done separately in Jambi City Health Office as there is no structured program planning for the involvement of related institutions, which is the secretariat of the team of Regional Level DHF Pokjanal Level II, so it has not realized the synergy program planning and mutual support among the agencies involved in the prevention of DHF. However, the funding in Jambi City Health Office in eradicating DHF is one of the priorities of financing, especially for the development of jumantik and sismantik cadres with inter-program linkages.

Associated with the implementation of efforts to eradicate DHF, consisting of prevention, detection of patients, relief, reporting, disease surveillance, and epidemiological investigation, as well as an extension to the public, have become a serious concern from the government of Jambi City. In the prevention aspect, the PSN movement is continuously being campaigned and this has become a serious concern with the issuance of Instruction of the Mayor of Jambi Number 196 of 2015 on Control and Eradication of Dengue Fever in Jambi City through the implementation of PSN One Hour One Week simultaneously on Friday, followed by the second instruction Number 1 of 2016 on the handling of dengue fever through the efforts of PSN, abatization, and fogging throughout Jambi City with instructions to all health personnel in order to be ready and be prepared for all medical needs related to dengue disease.

However, the PSN movement simultaneously began to diminish and is always initiated by the health party through puskesmas with the involvement of related parties such as posyandu cadres and the sub-district party. The efforts to mobilize the PSN movement are also done by involving larva monitoring students (sismantik) in schools, although not all sub-districts in Jambi City. Sismantik program is considered quite effective considering the larval monitoring activities are not only implemented in schools but followed by monitoring larvae in the respective houses of the sismantik. In addition, health promotion programs are always pursued through campaigns on DHF to communities.

The discovery of patients from the community with the involvement of Head of neighborhood/ sub-village/head of hamlet reported that the health facility has not been effective yet. It continues to be campaigned by the Health Office through health promotion programs in order to improve community knowledge and attitude including first aid measures with the reporting flow from the community to health workers and the follow-up by involving the local Neighborhood head.

Meanwhile, disease surveillance is carried out by puskesmas officers, and epidemiological investigations are carried out by puskesmas staffs assisted by the community, and the head of the puskesmas reported them to the Head of Sub-district and the Jambi City Health Office along with the necessary countermeasures. The implementation has been done by involving Jumantik Cadre and Head of neighborhood/sub-village/head of hamlet but with the obstacle, which is the delay of the community in reporting the patient with the symptoms of DHF so that the report often has been treated in hospital and Jambi City Health Office actually get a report from the hospital. In addition, people still consider fogging as an effective way to break the chain of transmission so that many people request to have a fogging.

Another aspect is found in the epidemiological investigation stage that begins with the suspect report of dengue fever, followed by cross check to the patient's house by health officer and jumantik cadre, if found larvae and there is $20 \%$ of fever patients from the house examined then fogging is conducted, direct counseling at the time of examination with the help of jumantik cadres, and abatization. In addition, PSN activities are conducted in the neighborhoods and schools by involving all elements.

The activity continued with the guidance of jumantik and sismantik cadres with the main activity of periodic larvae examination (PJB). Periodic larvae examination is performed by the cadres as seen in the larvae free rate (ABJ) found in the last 3 years ranged from $80-100$, even in 2014 reached 91.11, as well as in 2015 at position 89.08, which almost meet the national target of 95 , but increasing cases in Jambi City continues to occur. The result of the larva examination was reported to the Health Office by the puskesmas and sent to the Head of the Sub-District. However, meetings in the sub-district are always initiated by the puskesmas, as well as meetings in Jambi City, which is still being initiated by the Jambi City Health Office.

Considering that efforts that have been made maximally by health personnel in Jambi City, it is necessary to stipulate a strategy for DHF based on strengths, weaknesses, opportunities, and challenges faced in eradicating DHF on the implementation aspects of the government policy in the eradication of DHF in Jambi City so that it can decrease the incidence of DHF. The results of ultrasound analysis (Urgency, Serious, Growth) using Likert scale (1-5) on the identification of factors are related to efforts in eradicating DHF, which can be seen in Table 1 . 
Table 1.

The Identification of Factors Related to DHF Eradication Efforts Based on Urgency (U), Serious (S), Growth (G)

\begin{tabular}{|c|c|c|c|c|c|c|}
\hline \multirow{2}{*}{ No. } & \multirow{2}{*}{ Aspects } & \multirow{2}{*}{ Strengths } & \multicolumn{3}{|c|}{ Criteria } & \multirow{2}{*}{ Total Value } \\
\hline & & & $\mathbf{U}$ & $\mathbf{S}$ & G & \\
\hline 1 & Organizing & $\begin{array}{l}\text { DHF urban village level working group has } \\
\text { been formed }\end{array}$ & 5 & 4 & 4 & 13 \\
\hline 2 & Organizing & $\begin{array}{l}\text { The availability of jumantik cadres in every } \\
\text { urban village }\end{array}$ & 5 & 5 & 5 & 15 \\
\hline 3 & Eradication Efforts & $\begin{array}{l}\text { Sismantik has been formed in some } \\
\text { elementary and junior high schools }\end{array}$ & 5 & 5 & 5 & 15 \\
\hline 4 & Funding & $\begin{array}{l}\text { Budge support that is quite big and has } \\
\text { become a priority for regional heads }\end{array}$ & 5 & 5 & 4 & 14 \\
\hline \multirow{2}{*}{ No. } & \multirow{2}{*}{ Aspects } & \multirow{2}{*}{ Weaknesses } & \multicolumn{3}{|c|}{ Criteria } & \multirow{2}{*}{ Total Value } \\
\hline & & & $\mathbf{U}$ & $\mathbf{S}$ & G & \\
\hline 1 & Eradication Efforts & $\begin{array}{l}\text { PSN activities are not integrated and not yet } \\
\text { routine }\end{array}$ & 5 & 5 & 5 & 15 \\
\hline 2 & Eradication Efforts & $\begin{array}{l}\text { Jumantik cadres' activities are still limited to } \\
\text { periodic larvae inspection, and there is no } \\
\text { spontaneity of the people in each house to } \\
\text { larvae inspection }\end{array}$ & 5 & 5 & 5 & 15 \\
\hline 3 & $\begin{array}{l}\text { Discovery of people } \\
\text { with the disease }\end{array}$ & $\begin{array}{l}\text { The discovery, help, and report are yet } \\
\text { to run effectively, in which there is no } \\
\text { involvement of neighborhood heads } \\
\text { towards the surveillance of people with DHF }\end{array}$ & 4 & 5 & 4 & 13 \\
\hline \multirow{2}{*}{ No. } & \multirow{2}{*}{ Aspects } & \multirow{2}{*}{ Opportunities } & \multicolumn{3}{|c|}{ Criteria } & \multirow{2}{*}{ Total Value } \\
\hline & & & U & $\mathbf{S}$ & G & \\
\hline 1 & Development & $\begin{array}{l}\text { The support of Jambi Mayor in the form of } \\
\text { Local Regulation and Circular Letter }\end{array}$ & 5 & 5 & 4 & 14 \\
\hline 2 & Organization & $\begin{array}{l}\text { The cooperation support from the relevant } \\
\text { institution and community-related to DHF } \\
\text { Eradication }\end{array}$ & 5 & 5 & 5 & 15 \\
\hline \multirow{2}{*}{ No. } & \multirow{2}{*}{ Aspects } & \multirow{2}{*}{ Threat } & \multicolumn{3}{|c|}{ Criteria } & \multirow{2}{*}{ Total Value } \\
\hline & & & $\mathbf{u}$ & S & G & \\
\hline 1 & Eradication Efforts & $\begin{array}{l}\text { Routine PSN movement, both in houses and } \\
\text { institutions environment }\end{array}$ & 5 & 5 & 5 & 15 \\
\hline 2 & Eradication Efforts & $\begin{array}{l}\text { The increase of quality and quantity of } \\
\text { jumantik and sismantik cadres with the } \\
\text { movement of one house one jumantik }\end{array}$ & 5 & 5 & 4 & 14 \\
\hline
\end{tabular}

Source: Primary Data

\section{B. DHF Eradication Strategies in Jambi City}

Based on the results of identification of factors related to eradication efforts according to USG priority, then obtained 2 key factors which are then included in the SWOT strategy formulation as in the Table 2.

From Table 2, can be formulated strategies as follows:
1) S-O Strategy (a strategy that utilizes the strength to make use of the opportunities):

1. To increase the quantity and quality of jumantik and sismantik cadres with Mayor's support in the form of activities regulation and budget support.

2. To increase the efforts in getting support from relevant agencies and communities in eradicating DHF through Mayor's support. 
Table 2.

SWOT Strategy Formulation towards DHF Eradication Efforts in Jambi City

\begin{tabular}{|c|c|c|}
\hline & STRENGTHS (S) & WEAKNESSES (W) \\
\hline INTERNAL & $\begin{array}{l}\text { The availability of jumantik cadres } \\
\text { in each urban village and sismantik } \\
\text { cadres in some schools } \\
\text { - The big budget support and it has } \\
\text { been a priority for regional heads }\end{array}$ & $\begin{array}{l}\text { - PSN activities are not integrated } \\
\text { and not routine } \\
\text { - The activity of jumantik cadres is } \\
\text { limited to periodic larvae inspection } \\
\text { only, and there has been no } \\
\text { spontaneity from community per } \\
\text { house for larva inspection }\end{array}$ \\
\hline OPPORTUNITIES (O) & $S=0$ & w - o \\
\hline $\begin{array}{l}\text { - Jambi Mayor's support in the form } \\
\text { of Local Regulation and Circular } \\
\text { Letter } \\
\text { - The cooperation support from } \\
\text { relevant agencies and communities } \\
\text { related to DHF eradication }\end{array}$ & $\begin{array}{l}\text { To increase the quantity and quality } \\
\text { of jumantik and sismantik cadres } \\
\text { with Mayor's support in the form } \\
\text { of regulations and activities budget } \\
\text { support } \\
\text { - To increase efforts to get support } \\
\text { from relevant agencies and } \\
\text { communities in eradicating DHF } \\
\text { through Mayor's support }\end{array}$ & $\begin{array}{l}\text { - Strengthen the implementation of } \\
\text { PSN integrated with agencies and } \\
\text { all elements of society with the } \\
\text { support of the Mayor } \\
\text { - Strengthen intergovernmental } \\
\text { coordination through related } \\
\text { agencies, sub-districts and } \\
\text { the equipment, as well as the } \\
\text { community to conduct periodic } \\
\text { larvae inspection in their respective } \\
\text { places }\end{array}$ \\
\hline THREATS (T) & $S-T$ & $\mathbf{W}-\mathbf{T}$ \\
\hline $\begin{array}{l}\text { - A routine PSN Movement both } \\
\text { in houses and institutions } \\
\text { environment } \\
\text { - The increase of quality and quantity } \\
\text { of jumantik cadres and sismantik } \\
\text { cadres with one house one } \\
\text { jumantik movement }\end{array}$ & $\begin{array}{l}\text { To increase the role of jumantik } \\
\text { cadres and sismantik cadres } \\
\text { through budget support in } \\
\text { campaigning routine PSN } \\
\text { movement both at houses and } \\
\text { institutions environment } \\
\text { - To increase budget support within } \\
\text { one house one jumantik movement } \\
\text { campaign }\end{array}$ & $\begin{array}{l}\text { - To improve coordination at } \\
\text { government and community levels } \\
\text { in conducting integrated and } \\
\text { routine PSN movements. } \\
\text { - To increase the role of health } \\
\text { promotion through PSN's healthy } \\
\text { movement "by and at your own } \\
\text { house" as a form of one house one } \\
\text { jumantik movement }\end{array}$ \\
\hline
\end{tabular}

Source: Primary Data

2) S-T Strategy (a strategy that utilizes the strength to cope with threats):

1. Increase the role of jumantik cadres and sismantik cadres through budget support in campaigning routine PSN movement both at houses and institution environment.

2. Increase budget support within one house one jumantik movement campaign.

3) W-O Strategy (a strategy that minimizes weaknesses to take advantage of opportunities):

1. Strengthen the implementation of PSN integrated with agencies and all elements of society with the support of the Mayor.

2. Strengthen intergovernmental coordination through relevant institutions, sub-districts and the equipment, as well as the community to conduct periodic larvae checks in their respective places.

4) W-T Strategy (a strategy that minimizes weakness and avoids threats):
1. Increase the coordination at government and community levels in conducting integrated and routine PSN movements.

2. Increase the role of health promotion through healthy PSN movement "by and at your own house" as a form of one jumantik one home movement.

The selection of alternative solutions is conducted with Mc. Namara's screening theory, by determining the 5 criteria assessed from each alternative i.e. effectiveness, ease, benefits, time, and cost, as described in Table 3.

Based on the analysis of the theory, a strategy with the highest score is established, namely increasing the role of jumantik cadres and sismantik cadres through budget support in campaigning routine PSN movement both in houses and institutions environment and institution. Jumantik cadres are a working group of DHF disease eradication activities at the village level in the village community resilience institution (LKMD) from the community in the surrounding 
Table 3.

Method and Scoring of Alternative Solutions by Mc. Namara

\begin{tabular}{|c|c|c|c|c|c|c|c|c|}
\hline No. & Alternative Solutions & Effectiveness & Ease & Benefits & Time & Cost & Total & Ranks \\
\hline 1 & $\begin{array}{l}\text { To increase the quantity } \\
\text { and quality of jumantik } \\
\text { and sismantik cadres with } \\
\text { Mayor's support in the } \\
\text { form of regulations and } \\
\text { activities budget support }\end{array}$ & 5 & 4 & 5 & 4 & 3 & 21 & 3 \\
\hline 2 & $\begin{array}{l}\text { To increase efforts to get } \\
\text { support from relevant } \\
\text { agencies and communities } \\
\text { in eradicating DHF through } \\
\text { Mayor's support }\end{array}$ & 4 & 4 & 5 & 4 & 3 & 20 & 4 \\
\hline 3 & $\begin{array}{l}\text { To increase the role } \\
\text { of jumantik cadres } \\
\text { and sismantik cadres } \\
\text { through budget support } \\
\text { in campaigning routine } \\
\text { PSN movement both at } \\
\text { houses and institutions } \\
\text { environment }\end{array}$ & 5 & 5 & 5 & 4 & 4 & 24 & 1 \\
\hline 4 & $\begin{array}{l}\text { To increase budget support } \\
\text { within one jumantik one } \\
\text { house movement campaign }\end{array}$ & 5 & 4 & 5 & 4 & 3 & 21 & 3 \\
\hline 5 & $\begin{array}{l}\text { To strengthen the } \\
\text { implementation of PSN } \\
\text { integrated with agencies } \\
\text { and all elements of society } \\
\text { with the support of the } \\
\text { Mayor }\end{array}$ & 5 & 4 & 5 & 3 & 4 & 21 & 3 \\
\hline 6 & $\begin{array}{l}\text { To strengthen } \\
\text { intergovernmental } \\
\text { coordination through } \\
\text { related institutions, } \\
\text { sub-districts and the } \\
\text { equipment, as well as the } \\
\text { community to conduct } \\
\text { periodic larvae inspection } \\
\text { in their respective places }\end{array}$ & 5 & 4 & 5 & 4 & 4 & 22 & 2 \\
\hline 7 & $\begin{array}{l}\text { To increase coordination } \\
\text { at government and } \\
\text { community levels in } \\
\text { conducting integrated and } \\
\text { routine PSN movements }\end{array}$ & 5 & 4 & 5 & 3 & 4 & 21 & 3 \\
\hline 8 & $\begin{array}{l}\text { To increase the role of } \\
\text { health promotion through } \\
\text { PSN } 3 \text { M Plus healthy } \\
\text { movement "by and at } \\
\text { your house" as a form of } \\
\text { one jumantik one house } \\
\text { movement }\end{array}$ & 5 & 4 & 5 & 4 & 4 & 22 & 2 \\
\hline
\end{tabular}

Source: Primary Data

environment who are voluntarily responsible for monitoring Aedes aegypti mosquito larvae in their territory (Directorate General of Disease Control and Environmental Health of the Department of
Health of the Republic of Indonesia, 1992).

As is known, DHF is an environmental-based disease, where Global Environmental Change (GEC), especially Global Warning, is responsible for DHF 
incidence. Many factors are known to contribute to the spread of DHF, namely environmental conditions, socioeconomic status, and geographic conditions. Of these many factors, geographical and environmental conditions contribute greatly. For example, the spread of DHF may increase at the beginning and the end of a rainy season. Temperature, humidity, and rainfall are the environmental conditions that determine the deployment of DHF (Wiweko, 2013).

In addition, there are still many community behaviors that have not been supportive in the eradication of DHF, such as a large number of community water reservoirs and the use of plastic packaging. Thus, the success of the DHF eradication program will be determined by many factors, such as population behavior, health personnel, early warning systems by the government, insecticide resistance, and allocation of funds for eradication programs (Sungkar, 2007).

Given the above conditions, of course, the success of DHF eradication program is not only determined by jumantik cadres factor alone. Various efforts have been made to cope with the increase in cases, and the most proven to reduce the incidence rate is to break the chain of transmission. This is done through community empowerment through PSN activities with 3M movement (drain, cover, bury). These activities have been intensified since 1992 and in 2000, developed into 3M Plus that is by using larvacide, maintaining fish, and preventing mosquito bites. Activity prevention of transmission is a major activity in the eradication of this disease, and the key to prevention is the strict monitoring of early reporting of Aedes aegypti vector population density including its larvae monitoring result, and the role of jumantik cadres is essential in this regard.

The vital role of the jumantik cadres in eradicating DHF is done through periodic larvae inspection (PJB) conducted through home visits every 3 months and reporting the results to the head of the urban village or health center on a regular basis at least weekly and monthly. The results obtained are reported in the form of Larvae Free Rate $(A B J)$ i.e. the ratio between the number of houses/ buildings without larvae with the number of inspected houses/buildings multiplied by $100 \%$. ABJ is an indicator of the spread of Aedes aegypti. $\mathrm{ABJ}$ is nationally targeted at more than 95\% (Sungkar, 2007). In addition, jumantik cadres provide education to families and communities, record and report DHF incidents to community units (RW), heads of hamlets, or puskesmas, conduct PSN and simple DHF eradication such as distributing abate powders and larvae-eating fishes (Directorate General of Communicable Disease Eradication and Environmental Health Ministry of Health Republic of Indonesia, 2004; Directorate General of Disease Control and Environmental Health of the
Department of Health of the Republic of Indonesia, 1992).

It is reported that in several DHF endemic areas, the jumantik program plays an effective role in reducing the DHF case. One of the endemic areas that has the highest DHF cases in 2011 is the Province of Bali. Jumantik program is quite instrumental in monitoring the environmental conditions of the community in the city of Denpasar, Bali, with the main focus on the urban areas with people that are quite dense and have high mobility. Jumantik program with special personnel is run and paid every month. Denpasar City Government indeed charges a lot of funds in the implementation of the program, but it is still smaller than the treatment budget (Purnama, 2011).

The next strategy is to strengthen intergovernmental coordination through related institutions, sub-districts and the equipment, as well as with the community in performing periodic larvae checks in their respective places. The strategy is a strategy for activating the community movement in PSN, such as clean Friday program, mass fumigation in high endemic villages and public places (schools, hospitals, puskesmas, mosques, churches, offices, markets), and periodic larvae inspection. To conduct community mobilization efforts, the involvement of government elements is a step that will certainly determine the success of the PSN program.

An infectious disease prevention policy, especially in the prevention of outbreaks, has been regulated in the form of legislation that is Law of the Republic of Indonesia Number 4 of 1984 on Infectious Disease Outbreak and Government Regulation Number 40 of 1991 on the Control of Infectious Disease Outbreaks. The regulation essentially regulates (1) the procedures for determining and revoking the placement of epidemic areas, (2) mitigation efforts, (3) community participation, (4) management of disease-causing substances, (5) compensation and rewards, 6) outbreak financing, and (7) reporting (Directorate of Nutrition and Community Health, 2006).

Various studies on risk factors of DHF incidence have been conducted and generally indicate that DHF control needs to be comprehensively carried out from various aspects, both medical and social, with the involvement of health workers and community empowerment. Community participation is crucial, especially in efforts to eradicate the vector which is the most important effort to break the chain of transmission. In the effort to eradicate the vector, the society plays an active role in periodic larvae monitoring and performing a simultaneous movement of PSN. Aedes aegipty mosquitoes are domestic mosquitoes that live very close to human settlements so that the eradication and prevention of 
disease are directed to eliminate the Aedes aegipty mosquito breeds in the neighborhood (Directorate of Nutrition and Community Health, 2006).

The PSN Movement with 3M Plus is followed by preventing mosquito bites by using anti-mosquitos scabbing, sleeping with mosquito nets, spraying the house with the most widely available mosquito repellent on the market, and other simple things by arranging the hangers well so that mosquitoes do not perch are the eradication efforts and the prevention of contagious DHF is highly determined by the community, which is more than $90 \%$ of the overall efforts (Directorate of Nutrition and Community Health, 2006). The successful implementation of DHF control policy related to community participation in Sendangmulyo Village is reported by Putri, Sudiro, \& W. (2012) research where the success is by effective communication between Urban Village and jumantik cadres, the availability of adequate resources, and the commitment from the head of urban village and community to reduce the number of cases of DHF, although there is no specific organizational structure in the implementation of the program.

Jambi City Government needs to increase health promotion efforts through healthy PSN movement "by and at your own house" as a form of one house one jumantik movement with the involvement of all elements of government from the highest level to the subdistrict and urban village level. DHF countermeasures are the responsibility of all related units and the general public. The combination of this case should also be done consistently. DHF prevention efforts should be done through preventive and promotive movements that may involve community discipline, rather than curative action. Efforts to increase community knowledge in order to raise awareness of healthy PSN 3 M Plus "by and at your own house" movement as a one house one jumantik movement is an effective step in DHF mitigation. Sungkar's research results, in 2010 found that the density and spread of Aedes aegypti and predictors of extraordinary events in three urban villages in Cempaka Putih sub-district decreased after counseling and PSN movement (Sungkar, 2010).

The development of community empowerment methods in the control of the DHF vector in Semarang City, Central Java, was conducted by Trapsilowati, Mardihusodo, Prabandari, \& Mardikanto (2015), and found that the application of community empowerment methods in DHF vector control (PMPV-DHF) in the intervention region can provide positive and significant differences with increased knowledge and attitudes on DHF. However, in community practice/action, despite an increase, is still not significant. Entomological evaluation in the intervention area with $\mathrm{ABJ}$ indicator has a tendency to increase, while indicators of $\mathrm{HI}, \mathrm{CI}$, and $\mathrm{BI}$ has a decreased tendency, and the region still has a potential to spread DHF.

The next strategy is to increase the quantity and quality of jumantik and sismantik cadres with Mayor's support in the form of regulation and budget support activities. Increasing the role of jumantik and sismantik cadres needs to be done, by revitalizing the role of jumantik, not only as the larva monitor but also as the real early guard in the vigilant effort against DHF outbreak. Certainly, this case requires the Mayor's support, both in regulations and budget support activities.

The revitalization effort of jumantik cadres has been done at the time of prevention of DHF outbreak in Jakarta, involving jumantik recruited from the community around DHF prone areas with a salary above UMR through training first. Significant results are shown in the decrease in DHF incidence rates. The same with the students' involvement in the DHF eradication. The programs implemented in Puerto Rico provide satisfactory results. The program includes providing knowledge of DHF to students, by demonstrating the Aedes aegypti larvae habitat at home and how to control it. Students also see and study the life cycle of mosquitoes, mode of transmission, larval habitats, and short videos on how to control Aedes aegypti. Results found there was an increase in parental involvement in the control of DHF (Sungkar, 2007).

The role of jumantik is crucial in monitoring the presence as well as impeding the early development of the DHF transmitting vector. The activeness of the jumantik cadres in monitoring their environment is an important step to prevent the increasing number of DHF cases. Therefore, it is necessary to increase the activity of jumantik through motivation by Health Department (Pratamawati, 2012). And it seems to be immediately realized by the government of Jambi City, especially the City Health Office of Jambi. Based on reports of periodic larvae conducted by Jumantik cadres in Jambi City, it is shown by ABJ that almost meets the national target of 89.08 in 2015, but still with an increase in cases in Jambi City. Immediate efforts are needed to increase the quantity and quality of jumantik cadres.

The same thing happened in North Jakarta. It was reported that $\mathrm{ABJ}$ in North Jakarta has reached $90 \%$ and some even reached $95 \%$, but in fact, the number of cases of DHF patients is still high. This fact means that the number of cases of DHF patients is not solely related to $\mathrm{ABJ}$. Based on these facts, it can be expected that high $\mathrm{ABJ}$ numbers may be caused by jumantik cadres with bad performance. One indicator is that jumantik cadres may be less thorough in conducting a survey. Jumantik may check only large water reservoirs such as tubs, buckets, and drums, while small containers such as 
flower vases, water reservoirs behind refrigerators, air-conditioner storage shelters, and drip dispenser shelters are not checked. Water reservoirs outside the home such as gutter, water tanks, used bottles, cans, plastic containers and so on sometimes are not checked. This resulted in the missing of Aedes aegypti larvae from the inspection. In addition, some homeowners do not allow their houses to be surveyed or houses in empty condition when the examination will be conducted (Sungkar, Widodo, \& Suartanu, 2006).

The next strategy is to increase budget support in one jumantik one house movement campaign. Increasing public awareness through promotional efforts with one jumantik one house movement campaign should be generated slowly but continuously. It is also in line with the strategy to strengthen the implementation of integrated PSN with agencies and all elements of society with the Mayor, which is certainly supported by the strategy to improve coordination at government and community levels in conducting integrated and routine PSN movement.

The last strategy is to increase efforts to get support from relevant agencies and communities in eradicating DHF through Mayor's support. The effectiveness of this strategy is deemed insufficient because the process of a community empowerment must be grown from the awareness of the community itself. However, the Mayor's support in the form of a local regulation will have a strong influence on the government, especially in budget priorities. In this case, a support for community empowerment programs in PSN should be prioritized over budget for fogging. Fogging can actually cause the potential for dengue fever vectors resistance to the insecticide used during fogging. Several research results have shown that the impact of the implementation of fogging that incidentally use insecticides has provoked a new problem in the form of DHF vector resistance to the type of insecticide used. Sunaryo, Ikawati, Rahmawati, \& Widiastuti (2014), in his study stated that DHF vectors in Central Java province have been resistant to Malathion 0.8\%, and Permethrin $0.25 \%$ in Semarang regency/ city. Kendal Regency and Purbalingga Regency are highly resistant to organophosphate group, while in Grobokan Regency, it is highly resistance to malathion $0.8 \%$ and permethrin $0.25 \%$.

\section{Conclusion}

Government policies related to the eradication efforts, which are a positive endorsement, will not be able to contribute to the decline in DHF incidence if they are not followed by efforts to eradicate through the involvement of all sectors and communities. Similarly, in the city of Jambi, where the Mayor's policies in eradication efforts have not been maximally implemented, especially in the implementation of the PSN movement by the community with the involvement of cross-sectoral integration, especially on budgeting. Considering this, the strategy that can be done is to increase the role of jumantik and sismantik cadres in motivating people to conduct PSN movements regularly and independently at home with budget support and program integration in related sectors.

Based on these conclusions, Jambi City Government is expected to prioritize support for PSN movement independently by the community in Jambi City through efforts to increase the role of jumantik cadres and sismantik cadres, of course, with budget support and integration of programs in sectors related to PSN movement.

\section{ACKNOWLEDGEMENT}

The researcher would like to thank the parties involved in this research, as well as reviewers, namely Dr. dr. Sotianingsih, SpPK, Dr. Sukmal Fahri MKes, Dr. Ummi Kalsum, MKes, and the Head of Research and Development Agency of Jambi Province.

\section{REFERENCES}

Aba, F. X. L., Yussof, O. M., \& Binti Mohd, S. (2015). Analysis of Economic Structure in Poverty Eradication in The Province of East Nusa Tenggara Indonesia. Procedia-Social and Behavioral Sciences, 211,81-88. http://doi.org/10.1016/j. sbspro.2015.11.013

ACAPS Briefing Notes: Indonesia Drought. (2016). ACAPS.

Alvarez, S. A., Barney, J. B., \& Newman, A. M. B. (2015). The Poverty Problem and the Industrialization Solution. Asia Pacific Journal Management, 32, 23-37. http://doi.org/10.1007/ s10490-014-9397-5

Andrianto, A. (2006). The Role of District Government in Poverty Alleviation: Case Studies in Malinau and West Kutai Districts, East Kalimantan, Indonesia. Bogor: Center for International Forestry Research. http://doi.org/10.17528/ cifor/002094

Badan Pusat Statistik. (2012). Profil Kemiskinan di Indonesia September 2012.

BPS-Statistics of Nusa Tenggara Timur Province. (2016). Nusa Tenggara Timur Province in Figures 2016. Jakarta: BPS-Statistics of Nusa Tenggara Timur Province.

Buhaerah, P. (2016). Poverty and Human Rights: New Direction in Poverty Eradication. Jurnal Bina Praja, 8(2), 221-230. http://doi. org/10.21787/jbp.08.2016.221-230

Fritzen, S. (2002). Growth, Inequality and the Future of Poverty Reduction in Vietnam. Journal 
of Asian Economics, 13(5), 635-657. http://doi. org/10.1016/S1049-0078(02)00173-2

Kementerian Kehutanan Pemerintah Provinsi Nusa Tenggara Timur. (2010). Masterplan Pengembangan dan Pelestarian Cendana Provinsi Nusa Tenggara Timur Tahun 2010-2030. Kupang: Kementerian Kehutanan Pemerintah Provinsi Nusa Tenggara Timur. Retrieved from http://library.forda-mof.org/libforda/koleksi-308-masterplan-pengembangan-dan-pelestarian-cendana-provinsi-nusa-tenggara-timur-tahun-20102030.html

Kwong, M., \& Ronnås, P. (2011). Employment Diagnostic Analysis: Nusa Tenggara Timur, Indonesia (No. 95). Employment Sector, Employment Working Paper. Geneva: International Labour Organization. Retrieved from http://www.ilo. org/employment/Whatwedo/Publications / working-papers/WCMS_162672/lang--en/index.htm

Law of the Republic of Indonesia Number 23 of 2014 on Regional Government, Pub. L. No. 23 (2014). Indonesia.

Masterplan Pariwisata Nusa Tenggara Timur 20132023. (2012). Kupang: Pemerintah Daerah Provinsi Nusa Tenggara Timur.

Masterplan Percepatan dan Perluasan Pembangunan Ekonomi Indonesia (MP3EI). (2011). Kementerian Koordinator Bidang Perekonomian \& Kementerian Perencanaan Pembangunan Nasional/Badan Perencanaan Pembangunan Nasional.

Mohamed, M. Z., \& Xavier, J. A. (2015). Poverty Alleviation Strategies and New Economic Model in Malaysia. International Academic Research Journal of Economics and Finance, 3(4), 17-31. Retrieved from http://acrpub.com/archive. php?jid=6\&archiveyear $=2015 \&$ archive month=March\&archivevolumn=3\&archiveissue $=4$

Olinto, P., Beegle, K., Sobrado, C., \& Uematsu, H. (2013). The State of the Poor: Where Are the Poor, Where Is Extreme Poverty Harder to End, and What Is the Current Profile of the World's Poor? Economic Premise, (125), 1-8. Retrieved from https://econpapers.repec.org/article/ wbkprmecp/ep125.htm

Page, T., Tate, H., Bunt, C., Potrawiak, A., \& Berry, A. (2012). Opportunities for the Smallholder Sandalwood Industry in Vanuatu (ACIAR Technical Reports No. 79). Canberra.

Partnership for Governance Reform. (2011). Kebijakan Pengelolaan Kawasan Perbatasan Indonesia (No. 2/2011). Jakarta. Retrieved from http://www.kemitraan.or.id/policy-paper/ policy-paper-no-22011-kebijakan-pengelolaan-kawasan-perbatasan

Priyanto, D., \& Diwyanto, K. (2014). Pengembangan Pertanian Wilayah Perbatasan Nusa Tenggara Timur dan Republik Demokrasi Timor Leste. Pengembangan Inovasi Pertanian, 7(4), 207-220. http://doi.org/10.21082/pip. v7n4.2014.207-220

Suryahadi, A., Suryadarma, D., \& Sumarto, S. (2006). Economic Growth and Poverty Reduction in Indonesia: The Effects of Location and Sectoral Components of Growth. SMERU Working Paper. Jakarta. Retrieved from http://smeru. or.id/en/content/economic-growth-and-poverty-reduction-indonesiathe-effects-location-and-sectoral-components

Taiwo, J. N., \& Agwu, M. E. (2016). Problems and Prospects of Poverty Alleviation Programmes in Nigeria. International Journal of Business and Management Review, 4(6), 18-30. Retrieved from http://www.eajournals.org/journals/ international-journal-of-business-and-management-review-ijbmr/vol-4-issue-6-august-2016/problems-prospects-poverty-alleviation-programmes-nigeria/

United Nations Conference on Trade and Development. (2014). Baseline Study for the National Green Export Review for Vanuatu. Port Vila: United Nations Conference on Trade and Development. 